\title{
Human disturbance affects habitat use and behaviour of Asiatic leopard Panthera pardus in Kaeng Krachan National Park, Thailand
}

\author{
Dusit Ngoprasert, Antony J. Lynam and George A. Gale
}

\begin{abstract}
Edge effects arising from road construction and other development in protected areas can negatively affect the behaviour of wildlife, particularly large carnivores. The Asiatic leopard Panthera pardus is a large carnivore that may be sensitive to edge effects. Camera trapping was used to assess the influence of human disturbance along forest edges on leopard behaviour and habitat use in a $104 \mathrm{~km}^{2}$ area of Kaeng Krachan National Park, Thailand. A minimum of four male and two female leopards was recorded in the study area. A Park access road bisecting the study area was not a barrier to leopard movement but movements and activity were affected by human traffic inside the Park. A regression model showed that leopard habitat use
\end{abstract}

increased with distance from human settlements at the forest edge. As in other parts of its range, leopards at Kaeng Krachan National Park tended to show less diurnal activity in areas more heavily used by people compared to areas less used. As is the case with tigers, such responses may pose a threat to leopard population persistence but more research is needed to determine the demographic implications of edge effects for Asiatic leopards and other large tropical carnivores, and the appropriate mitigation strategies required.

Keywords Asiatic leopard, carnivore, human disturbance, Panthera pardus, protected area management, Thailand.

\section{Introduction}

Large carnivores $(>20 \mathrm{~kg})$ are useful for monitoring and predicting ecological disturbance in human-dominated landscapes because they occur at low density, and have large home ranges, low reproductive rates, and highly acute sensory systems that make them susceptible to human activity and to changes in the configuration and connectivity of habitats such as those induced by fragmentation (Knight \& Eberhardt, 1985; Noss \& Cooperrider, 1994; Noss et al., 1996; Woodroffe \& Ginsberg, 1998; Soule \& Terborgh, 1999).

Roads that fragment wildlife habitats may negatively affect large carnivores through (1) modified behavioural responses such as home range shifts and reduced reproductive success (Trombulak \& Frissell, 2000), (2) direct mortality (Kerley et al., 2002; Kramer-Schadt et al., 2004), (3) reductions in prey availability (Kerley et al., 2002; Havlick, 2004), and (4) subdivision and isolation of populations (Forman \& Deblinger, 2000). Roads are

Dusit Ngoprasert and George A. Gale King Mongkut's University of Technology Thonburi, School of Bioresources \& Technology, 83 Moo 8 Thakham, Bangkhuntien, Bangkok 10150, Thailand.

Antony J. Lynam (Corresponding author) Wildlife Conservation Society, Asia Programs, 2300 Southern Boulevard, Bronx, NY, USA. E-mail tlynam@wcs.org

Received 4 November 2005. Revision requested 17 January 2006. Accepted 7 June 2006. conduits for human activity and may become barriers to carnivore movement because of vehicular traffic (Adams \& Geis, 1983; Lyon, 1983; Forman \& Alexander, 1998; Forman \& Deblinger, 2000; Trombulak \& Frissell, 2000; USDAFS, 2000). Hard-edged boundaries of protected areas, where natural habitat adjoins humandominated landscapes, are also places where increased mortality of carnivores occurs because of humancarnivore conflicts (Woodroffe \& Ginsberg, 1998).

In tropical Asia, protected areas typically lack buffer zones and are therefore hard-edged at their boundaries and often internally fragmented by roads. These areas are subject to incursions by local people who collect various forest products and sometimes poach wildlife. However, the risks to carnivores at roads and park boundaries have never been assessed. The Asiatic leopard Panthera pardus is a tropical large carnivore that has a wide distribution in Asia (Corbett \& Hill, 1992) and occurs across a range of habitat types and disturbance conditions (Sunquist \& Sunquist, 2002).

Understanding the responses of leopards to roads and park boundaries could assist in the development of more science-based wildlife conservation policy in protected areas. Thus, the objectives of this study were to (1) determine the relative influence of the natural environment versus the human-modified environment on leopards in Kaeng Krachan National Park, one of the largest contiguous landscapes for wildlife in South-east Asia but which lies adjacent to lands converted for human 
use, and (2) determine the movement and activity patterns of leopards in a part of the Park that receives heavy human use.

\section{Study area}

The 2,915 $\mathrm{km}^{2}$ Kaeng Krachan National Park, at altitudes of $100-1,513 \mathrm{~m}$, lies close to the junction of the Sundaic and Indochinese zoogeographic zones (Corbet \& Hill, 1992) and is Thailand's largest National Park (Fig. 1). Much of the topography is steep, with slopes $>30 \%$ covering $60 \%$ of the Park. Extensive contiguous forests change from dry evergreen in the north to semi-evergreen in the south, and support populations of globally threatened large mammals including tiger Panthera tigris and Asian elephant Elephas maximus, and threatened endemics such as Fea's muntjac Muntiacus feai. Along the eastern edge of the Park, lands have been converted for rice and fruit farming and cattle grazing. This study focused on Ban Krang, an area inside the National Park through which the main access road passes. The $36 \mathrm{~km}$ road includes both asphalt and dirt surfaces. Forests around

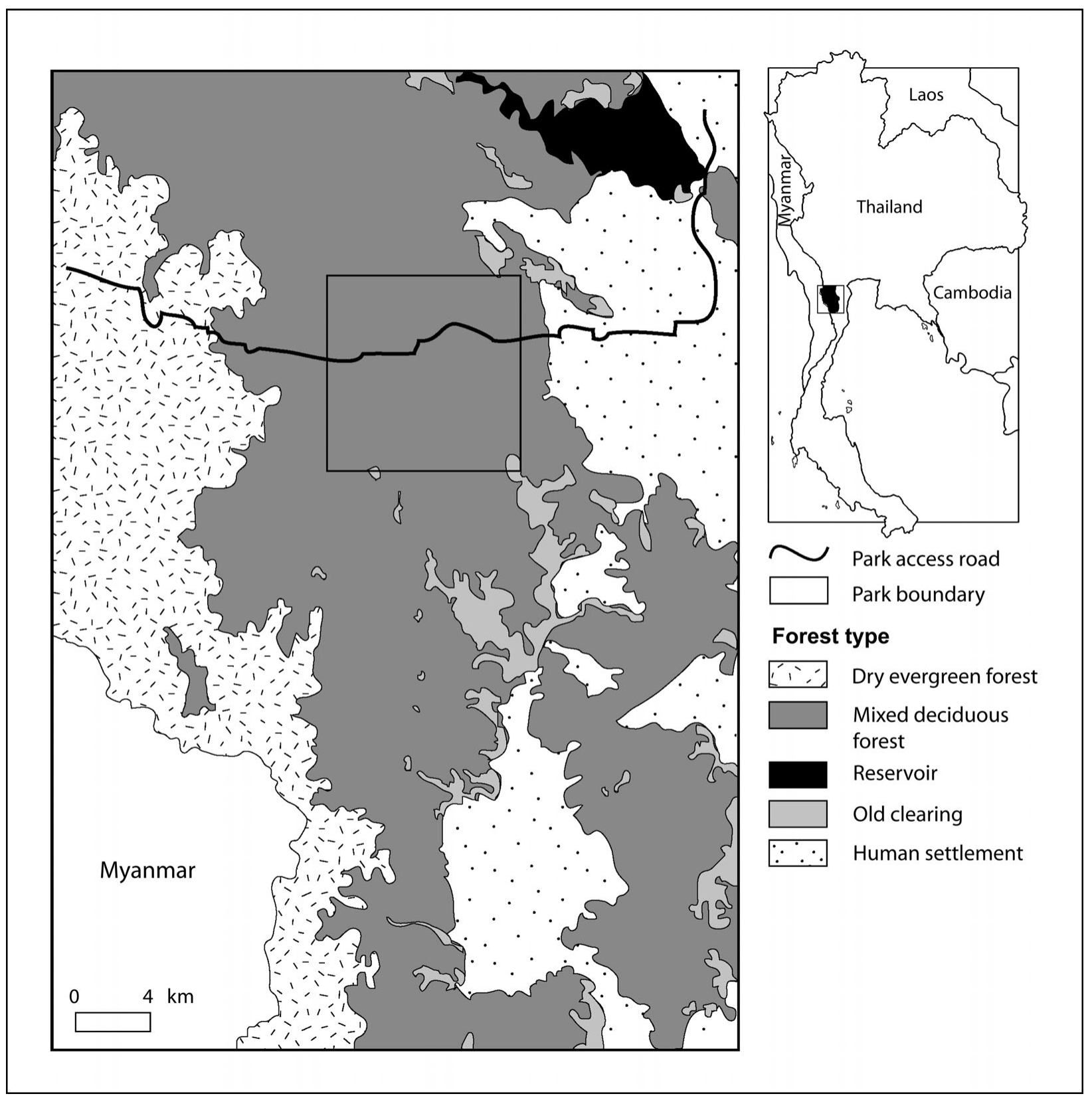

Fig. 1 The location of the Ban Krang study area in Kaeng Krachan National Park, showing details of vegetation types within the Park and the access road. The inset shows the location of Kaeng Krachan National Park in Thailand. 
Ban Krang are recovering from commercial logging of large ( $>1 \mathrm{~m}$ diameter at breast height) dipterocarp tree species (D. Marod, pers. comm.), which ended in 1989.

\section{Methods}

\section{Field surveys}

Asiatic leopards and other large mammals were sampled using passive infrared camera traps (Camtrakker, Camtrak South Inc., Georgia, USA). Large mammals were those recognizable to species level from photographs. Single camera traps were placed at optimal locations for detecting leopards (animal trails, mineral licks and stream beds) within the study area. A set of 72 trap locations was chosen following field reconnaissance in July-December 2002. Twenty-four traps were rotated through the 72 locations in 3-month trapping cycles. Each photograph was date and time stamped. Each camera trap was set for $24 \mathrm{~h}$, equivalent to one trap night. During each cycle, traps were established and operated for $19.8 \pm$ SE 0.3 trap nights. A relative abundance index (RAI) was defined by the number of independent photographs recorded per trap night and scaled up to 100 trap nights (O’Brien et al., 2003). However, because we did not measure the functional relationship with density (Carbone et al., 2001), RAI was interpreted as a measure of habitat use. Camera traps were also used to monitor movements of individual leopards, identified by their unique coat patterns. Leopards included spotted and black morphs but only the former could be individually distinguished in camera-trap photographs.

\section{Potential prey species for leopards}

A range of potential prey species have been identified for Asiatic leopards (Rabinowitz, 1989; Grassman, 1999). We defined potential prey species as those mammals occurring at $>40 \%$ of camera-trap locations in the study area. These species including bear macaque Macaca arctoides, East Asian porcupine Hystrix brachyura, large Indian civet Viverra zibetha, red muntjac Muntiacus muntjak, hog badger Arctonyx collaris, wild pig Sus scrofa and sambar Cervus unicolor. Total prey abundance was calculated by summing the values of RAI for these seven species.

\section{Landscape and disturbance variables}

At each trap location the nearest distances to the access road, villages at the Park boundary, mineral licks, and streams (landscape variables) were estimated using the Nearest Features v. 3.8a extension (Jenness, 2004) for the geographical information system ArcView v. 3.2a (ESRI Inc., Redlands, USA). Elevation at the study site was 298-616 m. All distance variables were normalized by log-transformation. One disturbance variable was human traffic, measured as the numbers of passes of humans in front of camera traps per trap night, scaled to 100 trap nights. For the purpose of this study, locations where humans were not detected by camera traps were defined as places with no human traffic, whereas locations where one or more human detections were recorded were defined as places with human traffic. A second disturbance variable was vehicle traffic measured as the total number of vehicles using the access road at Ban Krang per month. This was derived from vehicle entrance logbooks maintained by Park rangers.

\section{Data analysis}

For the analysis we assumed that leopard capture probabilities were relatively constant across the study area, so that RAI could be directly compared between trap stations. Univariate tests were used to assess differences in RAI near $(0-1 \mathrm{~km})$ and far $(>1 \mathrm{~km})$ from roads, streams, villages and mineral licks. The relative importance of landscape variables on variation in habitat use was determined using stepwise linear regression. Because of the possibility of non-independence caused by spatial autocorrelation and increased chance of type I error (Koenig, 1999) we tested for spatial autocorrelation in the regression residuals by calculating Moran's I statistic using the CrimeStat III software (N. Levine \& Associates, Houston, USA). The software tests the significance of Moran's I using a Z-test.

An index-based map of habitat use may provide an important tool for assessing space use in carnivores, and locations where leopards were detected or human traffic registered were mapped using ArcView. The Spatial Analyst extension to ArcView was used to identify core areas of leopard activity and show the minimum movement patterns for individual leopards, as well as concentrations of human activity. Interpolated surface functions were created as continuous surfaces from the sample points using an inverse distance weighted algorithm. This algorithm assumes that the similarity between points decreases with distance, and weights the interpolated points closer to the sample processing cell greater than those farther away (ESRI, 1996). Leopard activity was categorized from camera-trap records as either nocturnal (18.00-06.00) or diurnal (06.00-18.00). The activity of individual leopards was compared in areas with or without human traffic using $\chi^{2}$ tests.

\section{Results}

\section{Leopard abundance}

Between February 2003 and February 2004 a total of 4,493 camera trap nights recorded 161 photographs of 
leopard of which 146 photographs were identifiable as individuals, and 117 photographs were identifiable and had date and time stamps. This included a minimum of five spotted morph individuals (three males and two females), and at least one black morph individual (male). The RAI for leopards during the entire study was 3.58 detections per 100 trap nights, with an average of $2.71 \pm$ SE 0.39 detections per 100 trap nights (spotted and black morphs).

\section{Effects of landscape and disturbance variables on leopard abundance}

Human traffic across the study area was mostly of tourists $(62 \%)$, with the remainder being local people, Park staff and paramilitary personnel. At $74 \%$ of cameratrap locations no humans were recorded. Mean human traffic at the remainder of locations was 1.8 passes per 100 trap nights (range 1-38). Average vehicle traffic rate was separated into three categories using percentile rankings (low $<1$; medium 1-14; high $>14$; range $=0-31$ vehicles per day). Leopard RAI was not significantly different among different categories of vehicle traffic rates (KruskalWallis test, $\mathrm{P}>0.05)$.

Two independent variables, the nearest distance to the road and villages, were significantly correlated but only weakly so (Pearson's $R=0.31, \mathrm{P}<0.05$ ). The stepwise regression analysis indicated that only one variable, nearest distance to villages, was significant $\left(R^{2}=0.293\right.$, F-test $=28.97, \mathrm{df}=1, \mathrm{P}<0.05)$, with leopard RAI increasing with distance from the nearest village (RAI $=$ $-82.02+9.27 * \ln ($ distance $))$. The residuals from this regression were not significantly autocorrelated (Moran's $I=0.020, \mathrm{P}>0.05)$. However, the error variance was not homogeneous for different distances from the villages (Levene's Test, $\mathrm{P}<0.01$ ), indicating that a nonparametric or randomization test was required to confirm this trend. Univariate tests suggested that leopard RAI was higher far from villages (Mann-Whitney
U-test $=172.5, \mathrm{P}<0.01)$, thus supporting the results of the regression. In addition, leopard RAI was higher far from roads (Mann-Whitney U-test $=400.5, \mathrm{P}<0.05$ ) and closer to streams (Mann-Whitney U-test $=395.5, \mathrm{P}<0.01$ ).

To ensure that distance to village reflected the responses of multiple individuals and was not the result of a single leopard whose home range was far from the villages, but visited several trapping stations, we assessed the results graphically (Fig. 2). Of the five spotted morphs that were captured multiple times only two individuals were detected at traps closest $(6.4 \mathrm{~km})$ to villages and then only on a few occasions. One individual was detected only at traps furthest $(11.8-13.1 \mathrm{~km})$ from villages. The black morph individual(s) were detected at sites $>8 \mathrm{~km}$ from villages.

\section{Leopard movement and behaviour}

Leopards used $>50 \%$ of the study area (Fig. 3). The Park entrance road was not a barrier to the movement of leopards because at least three males were photographed on both sides of the road. However, univariate tests (above) suggested that leopards tended to avoid areas near the road. Leopard activity was arrhythmic (Fig. 4) with most activity recorded during the daytime (99 of 161 photographs; 61\%). Leopards were primarily diurnal and crepuscular, with activity peaks during 07.00-11.00 and 14.00-20.00 and a peak of activity in the afternoon (16.00). Individual spotted morph leopards were more diurnal in areas with no human traffic $\left(\chi^{2} 3.971, \mathrm{df}=1, \mathrm{P}<0.05\right.$; Table 1). These leopards were also $59 \%$ more frequently detected in places with no human traffic than places with human traffic.

\section{Discussion}

Using camera traps we found that leopard habitat use in Kaeng Krachan National Park was 1.4-25 times higher

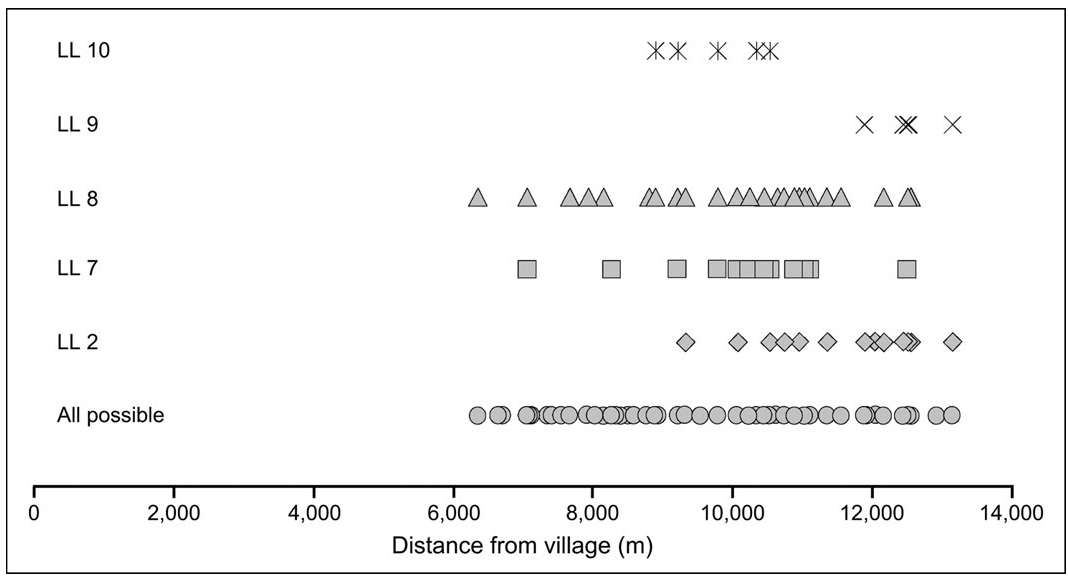

Fig. 2 Camera-trap records of five spotted morph Asiatic leopards (LL 2, 7, 89 and 10), separately and pooled, with respect to distance from nearest village. 


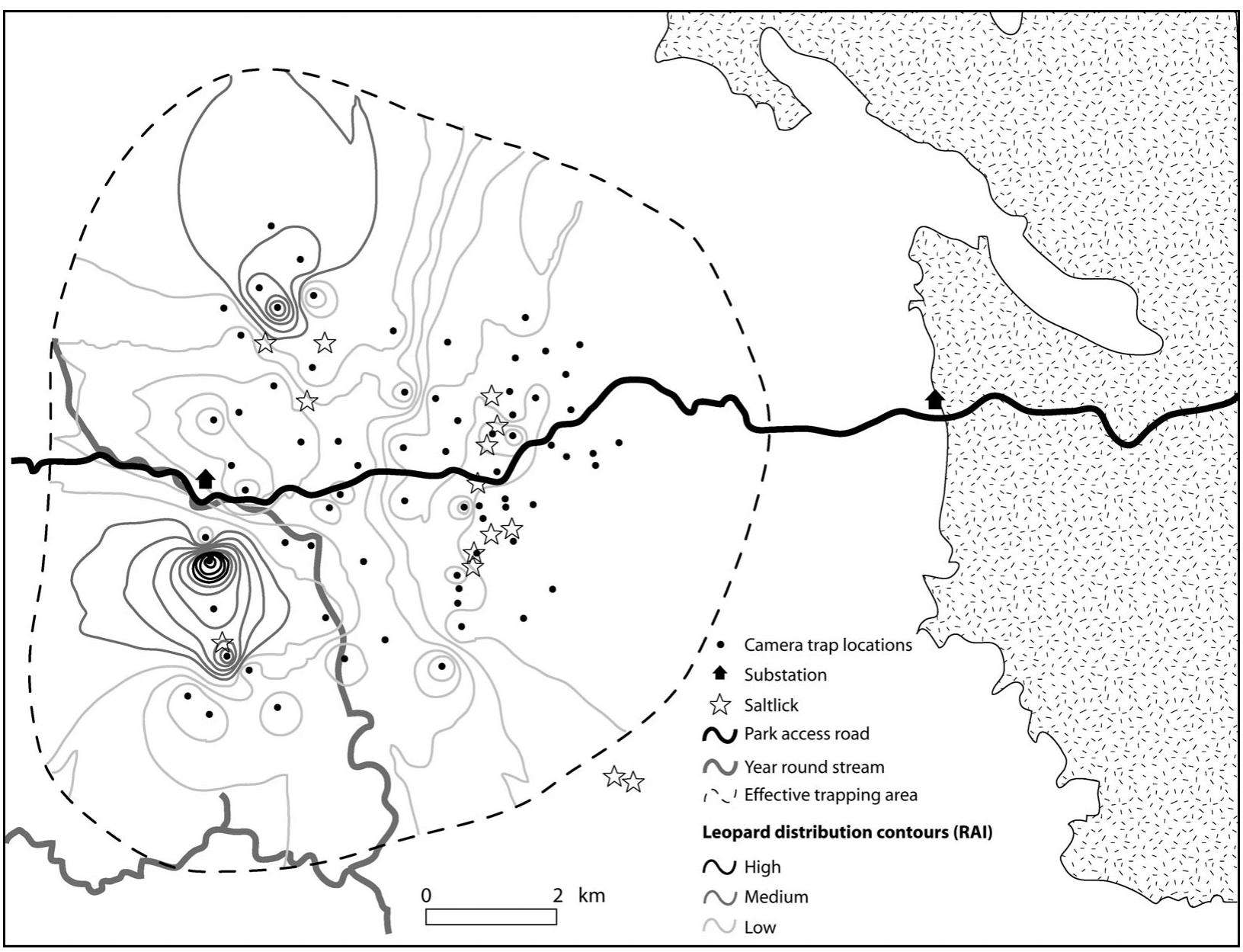

Fig. 3 Relative habitat use by Asiatic leopards in the study area. Leopard distribution contours were created using an inverse distance weighted algorithm function (see text for details).

than at other sites in central and southern Thailand, and elsewhere in South-east Asia (Table 2). At our undisturbed sites ( $<1 \mathrm{~km}$ from roads, no human traffic, $\mathrm{n}=22$ locations) leopards were detected more than twice as frequently in camera traps as large Indian civet (3.71 vs 1.56 detections per 100 camera-trap nights), the next most frequently recorded large carnivore, seven times more frequently recorded than dholes (0.61 detections per 100 camera-trap nights), and 25 times more than tigers (0.15 detections per 100 camera-trap nights), suggesting leopard is the dominant large carnivore. Although univariate tests suggested an effect of streams relative to human-related factors, natural habitat variables measured here (distance to streams and mineral licks) did not significantly affect leopard abundance. Although the impacts on vegetation from past logging (which we did not measure) could have influenced leopard distribution, this influence did not appear to be mediated via effects on the common prey species (see below).
Leopard used forest areas 6-14 km from human settlements at the Park boundary (Fig. 2), with habitat use increasing with distance from villages (Fig. 3), suggesting an edge effect. Leopards may be sensitive to changes at the Park boundary for several reasons. One explanation is that because leopards are obligate predators their populations should vary according to prey levels. Prey species abundance may be reduced, for example, due to poaching close to forest edges (Glanz, 1991; Bodmer et al., 1994; Carrillo et al., 2000; Robinson \& Bennett, 2000) or near human settlements (Johnson et al., 2006). However, seven potential leopard prey species were widely detected at camera locations in the study area, with multiple species of ungulates recorded at some locations, and abundances of these species did not vary with proximity to villages (Mann Whitney U-test, $\mathrm{P}>0.05)$. Although leopard diets at Kaeng Krachan National Park apparently include primates and smallbodied species (Grassman, 1999; D. Ngoprasert, pers. 


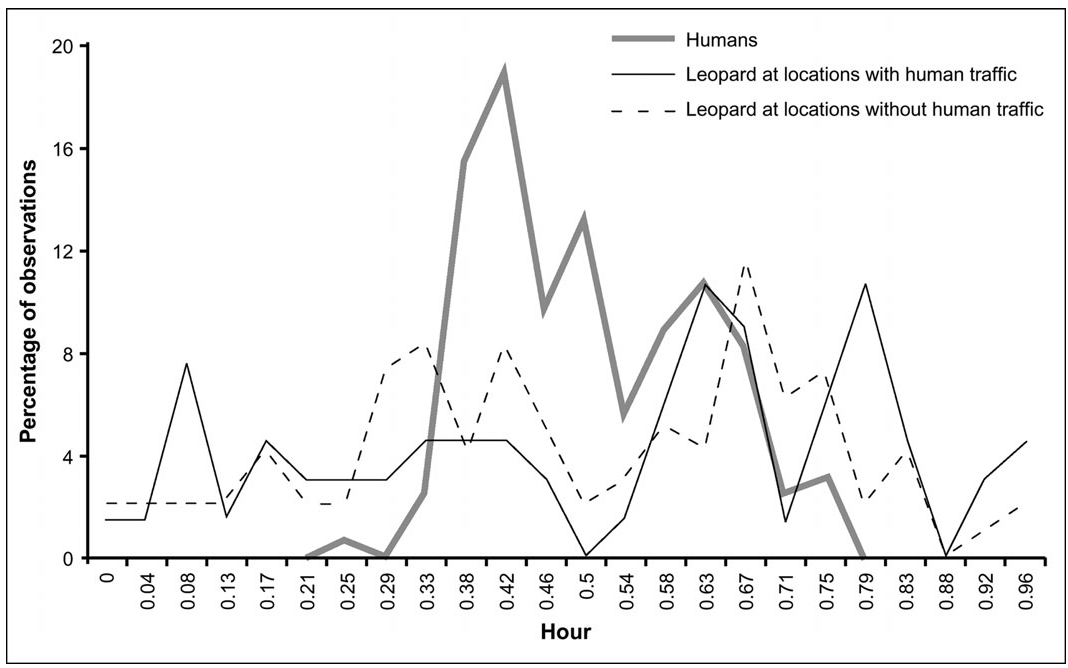

Fig. 4 Activity patterns (percentage of observations) of humans, and of leopards at locations with and without human traffic. obs.), and these taxonomic groups are under-sampled by camera traps, for the majority of larger prey species, e.g. M. muntiacus, S. scrofa, C. unicolor, camera traps permit both reliable detection and estimation of abundance (O'Brien et al., 2003). Additionally, prey abundance per se was not an important determinant of leopard habitat use. Therefore, we conclude that sensitivity to variation in prey abundance was not a likely explanation for the avoidance of forest edges by leopards.

Another explanation for the edge effect is that poaching at the Park boundary reduces the abundance of the carnivores themselves (Woodroffe and Ginsberg, 1998). However, although traps, shotgun cases, and hunting apparatus were occasionally found in the study area, and there was evidence of a bear (P. Manopawitr, pers. comm.) and a tiger (D. Ngoprasert, pers. obs.) caught in snares, we did not find any evidence of leopards killed by humans. Therefore, we believe the effect of direct poaching on leopards in the study area is negligible.

Alternatively, human traffic could explain the response of leopards to the edge. Although levels of human traffic were not different near and far from

Table 1 Percentage activity patterns of five individual white morph leopards.

\begin{tabular}{llll}
\hline & $\begin{array}{l}\text { Number of } \\
\text { photographs } \\
(\mathrm{n}=120)^{*}\end{array}$ & $\begin{array}{l}\text { \% diurnal } \\
(06.00-18.00)\end{array}$ & $\begin{array}{l}\text { \% nocturnal } \\
(18.00-06.00)\end{array}$ \\
Leopard & 28 & 64 & 36 \\
LL 1 (male) & 21 & 52 & 48 \\
LL 7 (male) & 48 & 52 & 48 \\
LL 8 (male) & 7 & 86 & 14 \\
LL 9 (female) & 16 & 69 & 31 \\
LL 10 (female) & 16 & \\
\hline
\end{tabular}

*Number of photographs with visible time and date on film villages, it may be the kind of human traffic that affects leopards. Human disturbance at Ban Krang was primarily from tourist traffic but also included border patrol police and Park ranger field patrols, as well as movements of local people. However, in places near the Park boundary away from the access road tourist activity is minimal and human traffic mostly comprises local people making forays into the forest to collect wild fruits, e.g. Parkia timoriana, and other non-forest timber products, and to poach wildlife such as langurs Cercopithecidae spp., pangolins Manidae spp., squirrels Sciuridae spp., civets Viverridae spp. and turtles. Although leopards use places frequented by humans, leopards were more diurnal in places with no human traffic. Moreover, encounters with people carrying guns or traps are likely to be more dangerous for a leopard than encounters with tourists, thus leading them to avoid areas near villages at the Park boundary. Elevated levels of human traffic associated with poaching may be facilitated by changes in forest structure at the Park boundary. Logging activities prior to 1989 have apparently reduced the density of large trees (D. Marod, pers. comm.), opening up the forest, and making access on foot easier. Although poacher traffic constituted $<13 \%$ of all human foot traffic in the study area, the elevated risk to leopards from poacher traffic close to villages is a likely cause of reduced leopard abundance and altered behaviour.

Leopard abundance was reduced near the park access road but vehicular traffic rate did not appear to influence leopards except during periods of peak traffic, such as during holidays. However, we suspect that outside peak traffic periods and at night when vehicle traffic is reduced, the risk of contact with humans or vehicles is low and leopards may venture close to and cross the access road. Leopards may also use the road as 
Table 2 Occurrence of Asiatic tiger and leopard determined from camera trapping in Kaeng Krachan National Park, Thailand (this study), and five other sites in South-east Asia. Numbers are total independent photographs, and numbers in parentheses are independent photographs per 100 trap nights (RAI).

\begin{tabular}{lcrrrr}
\hline Site & $\begin{array}{l}\text { Area sampled } \\
\left(\mathrm{km}^{2}\right)\end{array}$ & $\begin{array}{l}\text { Total trap } \\
\text { nights }\end{array}$ & \multicolumn{1}{c}{ Tiger } & Leopard & Source \\
\hline Taman Negara, Malaysia & 600 & 14,054 & $61(0.43)$ & $150(1.07)$ & Kawanishi \& Sunquist, 2004 \\
Tanintharyi, Myanmar & 285 & 244 & $0(0.00)$ & $5(2.05)$ & Lynam, 2003 \\
Myintmoletka, Myanmar & 310 & 341 & $1(0.29)$ & $0(0.00)$ & Lynam, 2003 \\
Khao Sok National Park, Thailand & 24 & 271 & $0(0.00)$ & $7(2.58)$ & Lynam, 1996 \\
Ta Phraya National Park, Thailand & $<100$ & 1,384 & $0(0.00)$ & $2(0.14)$ & Lynam et al., 2006 \\
Kaeng Krachan National Park, Thailand & 100 & 4,493 & $10(0.22)$ & $161(3.58)$ & This study \\
\hline
\end{tabular}

a travel corridor (DN and AJL, pers. obs.) as do other carnivores (Kerley et al., 2002). The average traffic rate in the Ban Krang study area is lower (17 vehicles per day) compared with other forest sites where large cats occur (77 vehicles per day, Kawanishi, 1995; 4.2 vehicles per hour, Kerley et al., 2002). It is unclear whether leopards in the Park would be affected if traffic rates increased dramatically.

Leopard is considered to be the generalist large carnivore that is least sensitive to disturbance (Sunquist \& Sunquist, 2002). However, our study clearly demonstrated adverse effects on leopards from human presence and activity, suggesting that beyond a certain threshold, effects on populations may be evident. This may indicate problems for more sensitive carnivores. For example, tigers, with larger home ranges, were rarely recorded at the study site, and may be largely restricted to areas in the west of Kaeng Krachan National Park where wild cattle prey populations are concentrated, and where access is limited because of an absence of roads and established foot trails, and human traffic is low.

Increasing numbers or activity of humans in a protected area increases the likelihood of encounters with large carnivores and this may have negative effects on the survival of sensitive species through several mechanisms (Woodroffe \& Ginsberg, 1998; Woodroffe, 2000). Humans disturbing carnivores while they hunt or feed may affect carnivore survival by causing predation to be less efficient (Kerley et al., 2002). This may be detrimental to carnivores but in turn may lead to increases in otherwise vulnerable species (Isbell \& Young, 1993). In areas with continuous human traffic, such as close to villages, this effect may lead to permanent changes in community structure that are similar to the long-term effects of hunting (Griffiths \& van Schaik, 1993). Roads may affect carnivore survival because of collisions with vehicles but perhaps more importantly because they increase access for poachers (Kerley et al., 2002). Because of these influences of human disturbance a strategy adopted by carnivores and other species sensitive to human presence is to change their behaviour by becoming more nocturnal (Haltenorth \& Diller, 1977; Griffiths \& van Schaik, 1993). Leopards may adopt nocturnal behaviour at forest edges and near roads in order to reduce encounters with humans (Sunquist, 1981). Our findings support the premise that leopards avoid forest edges and change their behaviour in response to human disturbance.

Most reserves in Thailand and elsewhere in Southeast Asia have hard edges, as at the eastern border of Kaeng Krachan National Park. Moreover, most are completely surrounded by these hard edges, and few abut large expanses of unbroken wildlife habitat, as in the western part of the Park. Management of protected areas with hard edges should focus on regulating human access across their boundaries (Rowcliffe et al., 2004), and these edges may help to separate carnivores from humans if (1) the boundaries are respected by people living at the edge, (2) the boundaries are patrolled and monitored by reserve staff, and (3) penalties are applied to discourage illegal incursions. In general, poaching can be reduced and protection increased by increasing numbers of active enforcement staff (Bruner et al., 2001), increasing enforcement effort through patrolling, guarding and investigations, and directing enforcement efforts towards problem areas inside the reserves. At the same time, restricting tourist access to specified recreation areas inside reserves may help to reduce disturbance to populations of leopards and their prey species. Human impacts can be mitigated through zoning to separate recreation areas from strict conservation areas and limited use areas, by establishing limits on the number of visitors entering a park at one time, and by careful management of tourist activities. For example, at Kaeng Krachan National Park wildlife watching towers located along the access road in areas with sufficient wildlife, but away from key mineral licks that attract large ungulates, may help to focus visitor traffic. The use of public vehicles for transporting people 
in and out of parks will help reduce impact of humans on sensitive areas, and increase the chances of viewing wildlife. This is important as numbers of tourists and traffic are predicted to increase in Asian parks.

The Kaeng Krachan National Park authorities have used the results of this study to improve management. One immediate outcome has been the closing of the Park during the wet season (May - October) to reduce disturbance to leopards and other wildlife. To gather further information on the effects of human disturbance a possible next step should be to examine demographic responses of leopards and other carnivores to forest edges.

\section{Acknowledgements}

The authors wish to thank the following individuals and institutions for facilitating and supporting this work: Director-General, Department of National Parks, Wildlife and Plants Conservation; Director, Office of National Parks; Manote Karnpanakngarn, Superintendent of Kaeng Krachan National Park and his staff. Fieldwork was done with the assistance of Prawing Klinklay, Tongbai Charoendong, Rawang Klinklay, Vichai Klinklay, Son Jitkum, Sutha Chansuk, Mana Charoengwai, Chaiwat Harnnarong and Pratthana Puangpratum. Funding was provided by a Thailand Government TRF/BIOTEC Special Program for Biodiversity Research and Training grant BRT R_346001, King Mongkut's University of Technology, Thonburi, and the Wildlife Conservation Society - International Programs. Justina Ray and Luke Hunter provided particularly helpful comments on early drafts of the manuscript, and Bill Kristan assisted with the statistics.

\section{References}

Adams, L.W. \& Geis, A.D. (1983) Effects of roads on small mammals. Journal of Applied Ecology, 20, 403-415.

Bodmer, R.E., Fang, T.G., Moya, L. \& Gill, R. (1994) Managing wildlife to conserve Amazonian rainforest: population biology and economic considerations of game hunting. Biological Conservation, 6, 1-7.

Bruner, A.G., Gullison, R.E., Rice, R.E. \& da Fonseca, G.A.B. (2001) Effectiveness of parks in protecting tropical biodiversity. Science, 291, 125-128.

Carbone, C., Christie, S., Conforti, K., Coulson, T., Franklin, N., Ginsberg, J., Griffiths, M., Holden, J., Kawanishi, K., Kinnaird, M., Laidlaw, R., Lynam, A., Martyr, D., McDougal, C., Nath, L., O’Brien, T., Seidensticker, J., Smith, J.L.D., Sunquist, M., Tilson, R. \& Shahruddin, W.N.W. (2001) The use of photographic rates to estimate densities of tigers and other cryptic mammals. Animal Conservation, 4, 75-79.

Carrillo, E., Wong, G. \& Cuaro, A.D. (2000) Monitoring mammal populations in Costa Rican protected areas under different hunting restrictions. Conservation Biology, 14, 1580-1591.
Corbett, G.B. \& Hill, J.E. (1992) Mammals of the Indomalayan Region: A Systematic Review. Natural History Museum Publications and Oxford University Press, London and Oxford, UK.

Forman, R.T.T. \& Alexander, L.E. (1998) Roads and their major ecological effects. Annual Review of Ecology and Systematics, 29, 207-231.

Forman, R.T.T. \& Deblinger, R.D. (2000) The ecological roadeffect zone of a Massachusetts (U.S.A.) suburban highway. Conservation Biology, 14, 36-46.

Glanz, W.E. (1991) Mammalian densities at protected versus hunted sites in Central Panama. In Neotropical Wildlife Use and Conservation (eds J.G. Robinson \& K.H. Redford), pp. 163-173. University of Chicago Press, Chicago, USA.

Grassman, L.I. (1999) Ecology and behavior of the Indochinese leopard in Kaeng Krachan National Park, Thailand. Natural History Bulletin of the Siam Society, 47, 77-93.

Griffiths, M. \& van Schaik, C.P. (1993) The impacts of human traffic on the abundance and activity periods of Sumatran rain forest wildlife. Conservation Biology, 7, 623-626.

Haltenorth, T. \& Diller, H. (1977) Die Saugetiere Afrikas and Madagaskars. BLV Verlagsgesellscjaft $\mathrm{mbH}$, Munich, Germany.

Havlick, D. (2004) The deer is broken, legs akimbo and lies ragged the side of the road. Conservation in Practice, 5, 31-34.

Isbell, L. \& Young, T.P. (1993) Human presence reduces predation in a free-ranging vervet monkey population in Kenya. Animal Behaviour, 45, 1233-1235.

Jenness, J. (2004) Nearest features (nearfeat.avx) extension for ArcView 3.x v.3.8a. Jenness Enterprises, Flagstaff, Arizona, USA [http://www.jennessent.com/arcview/ nearest_features.htm, accessed 18 January 2007].

Johnson, A., Vongkhamheng, C., Hedemark, M. \& Saithongdam, T. (2006). Effects of human-carnivore conflict on tiger (Panthera tigris) and prey populations in Lao PDR. Animal Conservation, 9, 421-430.

Kawanishi, K. (1995) Camera monitoring of human impacts on rainforest wildlife in Tikal National Park, Guatemala. MSc thesis, Frostburg State University, Frostburg, Maryland, USA.

Kawanishi, K. \& Sunquist, M.E. (2004) Conservation status of tigers in a primary rainforest of Peninsular Malaysia. Biological Conservation, 120, 333-348.

Kerley, L.L., Goodrich, J.M., Miquelle, D.G., Smirnov, E.N. \& Quigley, H.B. (2002) Effects of roads and human disturbance on Amur tigers. Conservation Biology, 16, 97-108.

Knight, R.R. \& Eberhardt, L.L. (1985) Population dynamics of Yellowstone grizzly bears. Ecology, 66, 323-334.

Koenig, W.D. (1999) Spatial autocorrelation of ecological phenomena. Trends in Ecology and Evolution, 14, 22-26.

Kramer-Schadt, S., Revilla, E., Wiegand, T. \& Breitenmoser, W. (2004) Fragmented landscapes, road mortality and patch connectivity: modelling influences on the dispersal of Eurasian lynx. Journal of Applied Ecology, 41, 711-723.

Lynam, A.J. (1996) Distributions of Large Fauna with Respect to the Edge of a Thailand Protected Area. Unpublished Report, Wildlife Conservation Society, New York, USA.

Lynam, A.J. (2003) A National Tiger Action Plan for the Union of Myanmar. A report prepared for the Myanmar Forest Department Ministry of Forestry, Yangon, Myanmar.

Lynam, A.J., Round, P. \& Brockelman, W.Y. (2006) Status of Birds and Large Mammals of the Dong Phayayen-Khao Yai Forest Complex, Thailand. Biodiversity Research and Training Program and Wildlife Conservation Society, Bangkok, Thailand. 
Lyon, L.J. (1983) Road density models describing habitat effectiveness for elk. Journal of Forestry, 81, 592-595.

Noss, R.F. \& Cooperrider, A. (1994) Saving Nature's Legacy: Protecting and Restoring Biodiversity. Defenders of Wildlife and Island Press, Washington, DC, USA.

Noss, R.F., Howard, B.Q., Maurice, G.H., Troy, M. \& Paul, C.P. (1996) Conservation biology and carnivore conservation in the Rocky Mountains. Conservation Biology, 10, 949-963.

O'Brien, T.G., Kinnaird, M.F. \& Wibisono, H.T. (2003) Crouching tigers, hidden prey: Sumatran tiger and prey populations in a tropical forest landscape. Animal Conservation, 6, 131-139.

Rabinowitz, A. (1989) The density and behaviour of large cats in a dry tropical forest mosaic in Huai Kha Khaeng Wildlife Sanctuary, Thailand. Natural History Bulletin of the Siam Society, 37, 235-251.

Robinson, J.G. \& Bennett, E.L. (eds) (2000) Hunting for Sustainability in Tropical Forests. Columbia University Press, New York, USA.

Rowcliffe, J.M., Merode, E.D. \& Cowlishaw, G. (2004) Do wildlife laws work? Species protection and the application of a prey choice model to poaching decisions. Proceedings of the Royal Society, London, B, 271, 2631-2636.

Soule, M.E. \& Terborgh, J. (1999) Continental Conservation: Scientific Foundations of Regional Reserve Networks. Island Press, Washington, DC, USA.

Sunquist, M.E. (1981) The social organization of tigers (Panthera tigris) in Royal Chitwan National Park, Nepal. Smithsonian Contributions to Zoology, 336, 1-98.

Sunquist, M.E. \& Sunquist, F. (eds) (2002) Wild Cats of the World. University of Chicago Press, Chicago, USA.

Trombulak, S.C. \& Frissell, C.A. (2000) Review of ecological effects of roads on terrestrial and aquatic communities. Conservation Biology, 14, 18-30.
USDAFS (United States Department of Agriculture Forest Service) (2001) Forest Roads: A Synthesis of Scientific Information. General Technical Report PNW-GTR-509, United States Department of Agriculture Forest Service, Pacific Northwest Research Station, Portland, Oregon, USA.

Woodroffe, R. (2000) Predators and people: using human densities to interpret declines of large carnivores. Animal Conservation, 3, 165-173.

Woodroffe, R. \& Ginsberg, J.R. (1998) Edge effects and the extinction of populations inside protected areas. Science, 280, 2126-2128.

\section{Biographical sketches}

Dusit Ngoprasert conducted this study as part of his MSc research at King Mongkut's University of Technology Thonburi, Thailand, during 2000-2004. He was also an intern at the Wildlife Conservation Society Thailand Program. He is now engaged in research on bear ecology and conservation.

Antony Lynam directed the Wildlife Conservation Society's Thailand Program during 1996-2004 during which time he conducted research on large carnivores and trained protected area staff, researchers and graduate students in conservation science and management methods.

George Gale has worked in Thailand since 1998. He and his students have been focusing on the life histories and ecology of vertebrates, primarily birds and mammals. 